\title{
Dirofilaria immitis and Dirofilaria repens in mosquitoes from Corsica Island, France
}

Laidoudi Younes 1,2,3, Hélène Barré-Cardi ${ }^{4}$, Samia Bedjaoui ${ }^{5}$, Nazli Ayhan²,6, Marie Varloud ${ }^{7}$, Oleg Mediannikov,2, Domenico Otranto ${ }^{2,8}$ and Bernard Davoust ${ }^{1,2,9^{*}}$

\begin{abstract}
Background: Dirofilaria immitis and Dirofilaria repens are the main causative agents of heartworm disease and subcutaneous dirofilariasis in domestic and wild canids, respectively. Both pathogens have zoonotic potential and are transmitted by mosquitoes. The present study aimed to determine the transmission period, prevalence and diversity of Dirofilaria spp. vectors from endemic areas of Corsica (France).
\end{abstract}

Methods: A monthly point data model based on average temperature recorded by four meteorological stations during 2017 was used to calculate the Dirofilaria transmission period. From June to September 2017, female mosquitoes $(n=1802)$ were captured using Biogents ${ }^{\circledR}$ Sentinel 2 traps lured with carbon dioxide and BG-Lure ${ }^{\mathrm{TM}}$ or octanol. Mosquitoes were identified to species level, pooled accordingly, and screened using multiplex real-time qPCR to detect $D$. immitis and D. repens.

Results: The monthly point data model showed the possible transmission of Dirofilaria spp. from the third week in May to the last week in October in the studied area. Mosquitoes were identified as Ochlerotatus caspius $(n=1432)$, Aedes albopictus $(n=199)$, Culex pipiens sensu lato $(n=165)$ and Aedes vexans $(n=6)$ and were grouped into 109 pools (from 1 to 27 specimens, mean 11.4 \pm 0.7 ), of which 16 scored positive for Dirofilaria spp. (i.e., $n=13$; estimated infection rate $[E I R]=1.1 \%$ for $D$. immitis and $n=3 ; E I R=0.2 \%$ for $D$. repens). Specifically, 6 (i.e., EIR $=3.8 \%$ ) of 15 pools of $A e$. albopictus were positive for D. immitis, 2 of 14 of $C$. pipiens s.l. were positive for D. immitis and D. repens, respectively, and 8 of 77 pools of Oc. caspius were positive for D. immitis (i.e., $n=6$; $E I R=0.4 \%$ ) and D. repens (i.e., 2; $E I R=0.1 \%$ ). The highest mosquito infection rate was recorded in July $(E I R=2.5 \%)$, then in June $(E I R=1.3 \%)$ and September ( $E I R=0.6 \%)$.

Conclusions: The data suggest that both Dirofilaria species are endemic and occur possibly in sympatry in the studied area in Corsica, highlighting the need to implement preventive chemoprophylaxis and vector control strategies to reduce the risk of these filarioids in dog and human populations.

Keywords: Dirofilaria immitis, Dirofilaria repens, Mosquitoes, Transmission suitability, Corsica

\section{Background}

Dirofilaria immitis and Dirofilaria repens are zoonotic filarioid nematodes responsible for canine cardiopulmonary and subcutaneous dirofilariasis, respectively [1]. Dirofilaria immitis is of great veterinary importance

\footnotetext{
*Correspondence: bernard.davoust@gmail.com

${ }^{1}$ Aix Marseille Univ, IRD, AP-HM, MEPHI, Marseille, France

Full list of author information is available at the end of the article
}

while $D$. repens is the main causative agent of human dirofilariasis in the old world [2]. These mosquito-borne filarioids share the same definitive hosts (mostly canids), and several mosquitoes species (i.e., mosquitoes of the genera Culex, Aedes, Ochlerotatus, Anopheles, Coquillettidia, Armigeres, Mansonia and Psorophora) have been reported as competent vectors [3]. Several of these vectors feed indiscriminately on dogs and humans, resulting in a zoonotic sympatric occurrence in endemic areas [2]. original author(s) and the source, provide a link to the Creative Commons licence, and indicate if changes were made. The images or other third party material in this article are included in the article's Creative Commons licence, unless indicated otherwise in a credit line to the material. If material is not included in the article's Creative Commons licence and your intended use is not permitted by statutory regulation or exceeds the permitted use, you will need to obtain permission directly from the copyright holder. To view a copy of this licence, visit http://creativecommons.org/licenses/by/4.0/. The Creative Commons Public Domain Dedication waiver (http://creativeco mmons.org/publicdomain/zero/1.0/) applies to the data made available in this article, unless otherwise stated in a credit line to the data. 
Molecular detection of filarioid parasites from the bloodsucking arthropods is one of the most effective strategies for assessing the prevalence of vectors and/ or pathogens in a given area. For example, to assess the prevalence of canine filarioids, a molecular-based approach was recently proposed for the diagnostic and xenomonitoring of skin- and blood-associated microfilariae from dog ticks [4]. Therefore, two duplex realtime polymerase chain reaction (PCR) assays have been standardized for the xenomonitoring of $D$. immitis and $D$. repens in mosquito vectors $[5,6]$. Previous molecular xenomonitoring studies revealed the presence of at least three filarioid nematodes (i.e., D. immitis, D. repens and Setaria tundra) in several mosquito species in Europe, mostly belonging to the genera Aedes, Anopheles, Coquillettidia, Culex, Culiseta and Ochlerotatus [5-22].

Canine dirofilariasis is endemic in Southern Europe [23-26]. Corsica, a French island in the Mediterranean basin, is known as an epidemiological hotspot from which several cases of vector-borne diseases in humans and dogs are imported to the mainland. This is the case of D. immitis in dogs from Corsica $[27,28]$ and human dirofilariasis caused by D. repens in visitors to the island [29]. Previous epidemiological studies confirmed the circulation of Dirofilaria spp. in human, dog and mosquito (i.e., Ae. albopictus) populations from the island [6, 30, 31]. However, data on the seasonality of transmission, diversity of the Dirofilaria vector and prevalence are sparse. This work advances understanding of the transmission period, prevalence and potential vectors of Dirofilaria spp. from endemic areas of Corsica (France).

\section{Methods}

Study area and seasonal transmission of Dirofilaria spp.

Monthly point data (monthly average temperatures) recorded in 2017 from four meteorological stations (i.e., Aleria: $42^{\circ} 06^{\prime} 53^{\prime \prime} \mathrm{N}, 9^{\circ} 30^{\prime} 48^{\prime \prime} \mathrm{E}$; Solenzara: $41^{\circ} 55^{\prime} 36^{\prime \prime} \mathrm{N}, 9^{\circ} 24^{\prime} 19^{\prime \prime} \mathrm{E}$; Borgo: $42^{\circ} 33^{\prime} 17^{\prime \prime} \mathrm{N}, 9^{\circ} 25^{\prime} 41^{\prime \prime} \mathrm{E}$ and Solaro: $41^{\circ} 54^{\prime} 17^{\prime \prime} \mathrm{N}, 9^{\circ} 19^{\prime} 37^{\prime \prime} \mathrm{E}$ ) were obtained from https://www.prevision-meteo.ch/ and were processed as described elsewhere [32]. Briefly, mean monthly and weekly development units (DU) for Dirofilaria spp. were calculated using the monthly point data model by Cuervo et al. [32] for D. immitis. The DUs represented the predicted degrees Celsius above the threshold of $14{ }^{\circ} \mathrm{C}$, as described for D. immitis [33] and $D$. repens [34]. Mean monthly development units (mMDU) were calculated as $\mathrm{mMDU}=$ [mean monthly temperature-14]"30 for each month. Monthly Dirofilaria generations ( $\mathrm{mDG}$ ) were calculated by dividing the number of mMDU by the threshold of $130 \mathrm{DU}$ required for extrinsic development of one generation of microfilariae (L1) to infective larvae (L3) within the vector [34]. To determine the initial transmission period, weekly development units (WDU) were calculated for each week of each month as described elsewhere [32].

\section{Mosquito sampling and processing}

In June, July and September 2017, female mosquitoes $(n=1802)$ were captured from four sites (i.e., Aleria, Solenzara, Solaro and Borgo) in the department of Haute-Corse, Corsica, France. Mosquito capture was performed using Biogents ${ }^{\circledR}$ Sentinel $2(n=16)$ (Biogents AG, Regensburg, Germany) traps lured with carbon dioxide and BG-Lure ${ }^{\mathrm{TM}}$ (Biogents AG, Regensburg, Germany) or octanol (Biogents AG, Regensburg, Germany) in Aleria $(n=4)$, Solenzara $(n=4)$, Solaro $(n=6)$ and Borgo $(n=2)$. At each time period, traps were placed approximately $1.5 \mathrm{~m}$ above ground and were installed at 17:00 and recovered 4 days later around 10:00. Mosquitoes were individually identified to species level using morphological keys [35] and then pooled (from 1 to 27 specimens, mean $11.4 \pm 0.7$ ) by species, sampling dates and province.

One hundred and nine pooled (from 1 to 27, mean $11.4 \pm 0.7)$ female specimens were prepared. For each mosquito pool, a 10-min bead-based mechanical lysis was performed in the TissueLyser apparatus in the presence of $800 \mu \mathrm{l}$ of MEM medium (Sigma Aldrich). Mosquito lysates were centrifuged at 13,000 $\mathrm{g}$ for $3 \mathrm{~min}$, and genomic DNA was extracted from $200 \mu \mathrm{l}$ of the supernatant in the presence of $100 \mu \mathrm{l}$ of lysis buffer. Extraction was performed using the QIAcube kit (Qiagen, Courtaboeuf, France) according to the manufacturer's instructions. DNA was eluted in a final volume of $100 \mu \mathrm{l}$ and stored at $-20{ }^{\circ} \mathrm{C}$ until analysis. Finally, genomic DNA was analysed for the presence of Dirofilaria spp. using a multiplex real-time qPCR assay as described elsewhere [36].

\section{Data analysis}

Differences in Dirofilaria spp. infection were evaluated between mosquito species, sampling period and province using the analysis of covariance (ANCOVA) model within XLSTAT software (Addinsoft, Paris, France, 2018). The minimum infection rate (MIR) [37] and the estimated infection rate (EIR) [38] were calculated using the following formulas: $\operatorname{MIR}=(x / n) * 100$ and $\mathrm{ERI}=\left(1-(1-x / m)^{1 / k}\right) * 100$, where $x$ is the number of positive pools, $n$ is the total number of mosquitoes tested, $m$ is the number of mosquito pools and $k$ is the average number of mosquitoes in each pool. 


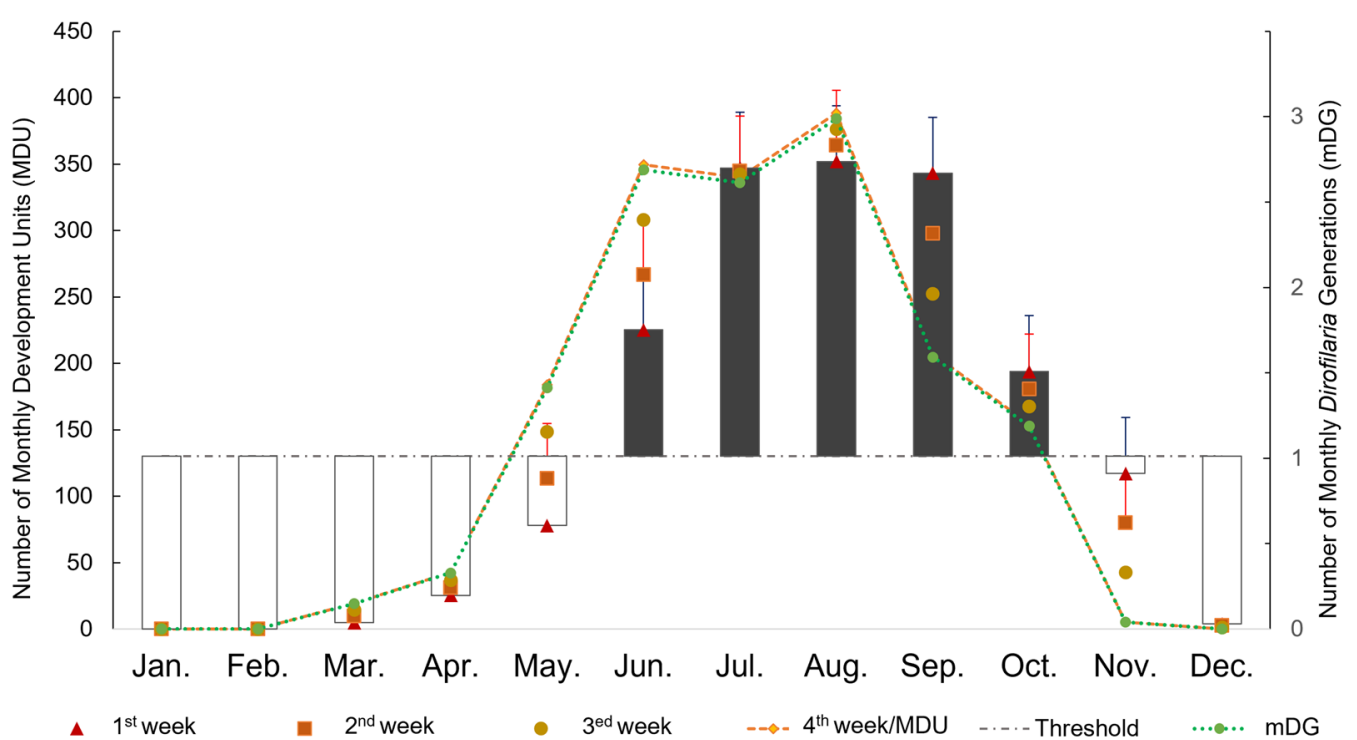

Fig. 1 An open-high-low-close chart showing the intensity and the time frame of the extrinsic incubation of Dirofilaria spp. within the vector in the studied area. Bars indicate the extinct (white) and active (grey) transmission period. Transmission intensity is represented by both generations (DG) and development units (DU) of Dirofilaria spp. on a weekly schedule. The fourth WDU of each month was considered equivalent to the corresponding MDU

\section{Results}

The monthly point data model indicated the potential transmission of Dirofilaria spp. for 22 weeks (from the third week in May to the last week in October) in the study area (Fig. 1). During the summer season (from July to September), up to $2.5 \mathrm{mDG}$ were recorded each month with a maximum activity of $3 \mathrm{mDG}$ in August (Fig. 1). Morphological identification of mosquitoes revealed the presence of at least four species, dominated by Ochlerotatus caspius $(n=1432 ; 79.8 \%)$ followed by Aedes albopictus ( $n=199,11.0 \%)$, Culex pipiens sensu lato $(n=165$; 9.2\%) and Aedes vexans ( $n=6 ; 0.3 \%)$. Most mosquitoes were caught in Solaro province $(n=1606 ; 89.1 \%)$, where the mosquito population was dominated by Oc. caspius $(n=1392 ; 86.7 \%)$ and Ae. albopictus $(n=168,10.5 \%)$. Mosquito abundance in the other provinces ranged from 25 specimens in Borgo to 83 and 88 specimens in Aleria and Solenzara, respectively. The highest number of mosquitoes ( $n=1496 ; 81.5 \%$ ) was caught during September (Fig. 2).

With the exception of the Ae. vexans pools, Dirofilaria spp. were detected in at least one mosquito pool per species with the highest infection rates for $D$. immitis in Ae. albopictus (MIR $=3 \%$; EIR $=3.8 \%$ ) and for $D$. repens in $C x$. pipiens s.l. $(\mathrm{MIR}=0.6 \%$; $\mathrm{EIR}=0.6 \%)$. Dirofilaria immitis was detected with the highest infection rates $(\mathrm{MIR}=2.2 \%$; EIR $=2.5 \%)$ in July, followed by June $(\mathrm{MIR}=1.2 \% ; \mathrm{EIR}=1.3 \%)$ and September $(\mathrm{MIR}=0.5 \%$; $\mathrm{EIR}=0.6 \%$ ). In contrast, $D$. repens was detected only in June $(\mathrm{MIR}=0.6 \% ; \mathrm{EIR}=0.6 \%)$ and September
$(\mathrm{MIR}=0.1 \% ; \mathrm{EIR}=0.1 \%)$. Dirofilaria were identified in two provinces surveyed (i.e., D. immitis in Solenzara and both species in Solaro provinces; Table 1).

\section{Discussion}

This study reports data on Dirofilaria spp. in mosquitoes collected in Corsica along with a prediction model to forecast the seasonal transmission of these filarioids, providing information about vector diversity and infestation rates with Dirofilaria spp. in Corsican mosquito species.

Dirofilaria transmission is related to an episystem complex involving several factors including temperature, vector and host abundance [2]. Data herein indicate that Dirofilaria transmission may occur over 22 weeks (from May to October), with maximum activity of 2.6 to $3 \mathrm{mDG}$ during the summer period (June to August), as reported in the southern regions of Europe [1], especially in Italy [39]. Interestingly, in this study, the highest MIR/ERI were recorded from Ae. albopictus in July, which coincides with the first peak of seasonal transmission (more than $2.6 \mathrm{mDG}$ ). Moreover, during the highest transmission peaks (June and July), mosquito fauna was dominated by Ae. albopictus and Cx. pipiens s.l., which are well-known vectors for Dirofilaria spp., therefore representing an epidemiological risk for infection to dogs and humans. It is worth noting that those are the months when a large number of tourists visit the island, often along with their pets. The relationship between prediction and actual prevalence of Dirofilaria has already been 


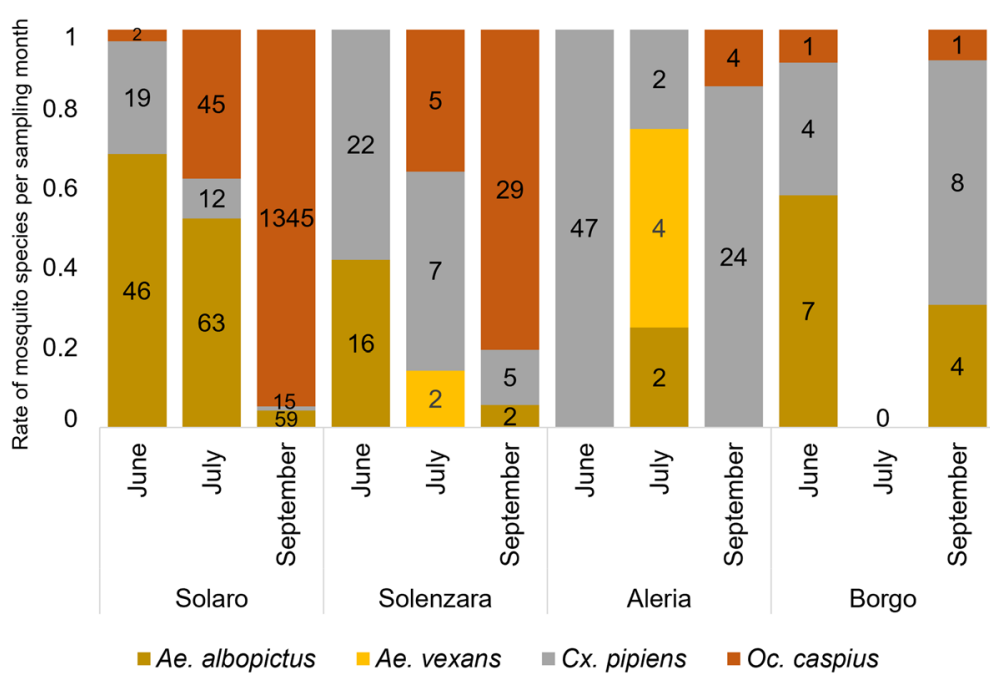

Fig. 2 Distribution of female mosquitoes according to their species, sampling month and province

confirmed in several studies [32, 40,41]. However, this period could be extended by the presence of heat islands, microenvironments such as buildings and parking lots retaining heat during the day. Consequently, the extrinsic development of Dirofilaria larvae becomes possible during the cold season [2, 42, 43]. Furthermore, some Dirofilaria vectors such as Cx. pipiens s.l. are known to overwinter as mated females, which may lead to the quick development of Dirofilaria larvae with subsequent warming periods $[42,44]$. Hence, in order to prevent

Table 1 Mosquito pools and their positivity for Dirofilaria spp. according to mosquito species, sampling month and province

\begin{tabular}{|c|c|c|c|c|c|c|c|c|c|}
\hline \multirow[t]{2}{*}{ Variables } & \multirow[t]{2}{*}{ Specimens $(n ; \mathrm{m} ; \mathrm{k} ; \mathrm{SE})$} & \multicolumn{4}{|c|}{ Dirofilaria immitis } & \multicolumn{4}{|c|}{ Dirofilaria repens } \\
\hline & & Positive pools & MIR & $E I R$ & $P$-value $P$-value ${ }^{\mathrm{a}}$ & Positive pools & MIR & $E I R$ & $P$-value $P$-value ${ }^{a}$ \\
\hline \multicolumn{10}{|l|}{ Mosquito species } \\
\hline Ochlerotatus caspius & $(1432 ; 77 ; 18.6 ; 0.5)$ & 6 & 0.4 & 0.4 & ref. & 2 & 0.1 & 0.1 & ref. \\
\hline Aedes albopictus & $(199 ; 15 ; 13.3 ; 2.2)$ & 6 & 3.0 & 3.8 & 0.0001 & 0 & na & na & 0.707 \\
\hline Aedes vexans & $(6 ; 3 ; 2.0 ; 0.6)$ & 0 & na & na & 0.757 & 0 & na & na & 0.566 \\
\hline Culexpipiens & $(165 ; 14 ; 11.8 ; 2.1)$ & 1 & 0.6 & 0.6 & 0.207 & 1 & 0.6 & 0.6 & 0.125 \\
\hline \multicolumn{10}{|l|}{ Sampling month } \\
\hline September & $(1496 ; 83 ; 18 ; 0.6)$ & 8 & 0.5 & 0.6 & ref. & 2 & 0.1 & 0.1 & ref. \\
\hline July & $(139 ; 12 ; 11.6 ; 2.3)$ & 3 & 2.2 & 2.5 & 0.406 & 0 & na & na & 0.701 \\
\hline June & $(167 ; 14 ; 11.9 ; 2.5)$ & 2 & 1.2 & 1.3 & 0.829 & 1 & 0.6 & 0.6 & 0.197 \\
\hline \multicolumn{10}{|l|}{ Province } \\
\hline Solaro & $(1606 ; 83 ; 19.4 ; 0.3)$ & 12 & 0.7 & 0.8 & ref. & 3 & 0.2 & 0.2 & ref. \\
\hline Aleria & $(83 ; 9 ; 9.2 ; 3.1)$ & 0 & na & na & 0.084 & 0 & na & na & 0.092 \\
\hline Solenzara & $(88 ; 9 ; 9.8 ; 2.6)$ & 1 & 1.1 & 1.2 & 0.211 & 0 & na & na & 0.232 \\
\hline Borgo & $(25 ; 8 ; 3.1 ; 0.8)$ & 0 & na & na & 0.025 & 0 & na & na & 0.192 \\
\hline Global infection rate & $(1802 ; 109 ; 11.4 ; 0.7)$ & 13 & 0.7 & 1.1 & na & 3 & 0.2 & 0.2 & na \\
\hline \multirow[t]{2}{*}{ Statistics } & & \multicolumn{4}{|c|}{ ANCOVA: $R_{(100)}^{2}=0.193$} & \multicolumn{4}{|c|}{ ANCOVA: $R_{(100)}^{2}=0.064$} \\
\hline & & \multicolumn{4}{|c|}{ ANCOVA: $F_{(8,108)}=2.993, P^{b}=0.005$} & \multicolumn{4}{|c|}{ ANCOVA: $F_{(8,108)}=0.861, P^{b}=0.552$} \\
\hline
\end{tabular}

ANCOVA statistics are also reported along with the percentage of minimum infection rate (MIR) and estimated rate of infection (ERI)

$n$, number of mosquito specimens; $m$, number of mosquito pools; $k$, average number of specimens per pools; $S E$, standard error; ref, fixed reference group for ANCOVA analysis; na, not applicable

a $P$-value calculated with Student's $t$-test within ANCOVA model for the effect of individual factors (i.e., mosquito species, sampling month and province) on Dirofilaria spp. infection

b $P$-value calculated with Fisher test within ANCOVA model for the global effect of grouped factors (i.e., mosquito species, sampling month and province) on Dirofilaria spp. infection 
Dirofilaria transmission in such areas, these factors have to be carefully considered when adopting chemoprophylaxis protocols, as already demonstrated in the field against Dirofilaria spp. infection in dogs [31].

The present data showed that Corsican mosquito fauna was dominated by Oc. caspius $(n=1432 ; 79.8 \%)$, which is in agreement with previous reports from southern Europe (Italy) $[45,46]$. In addition to confirming the previous report on Dirofilaria spp. from Ae. albopictus [6], the present data show for the first time the presence of Dirofilaria spp. DNA in Oc. caspius and $C x$. pipiens s.l. in France, as reported in previous European studies [5-22]. Despite the large natural infestation of European mosquitoes from endemic areas [5-22], only a few species have been experimentally confirmed as competent for Dirofilaria spp. (e.g., Cx. pipiens s.l., Ae. albopictus, Aedes aegypti, Aedes japonicus, Aedes geniculatus and Aedes koreicus) [47-50]. Under natural conditions, blood pathogens can be found in haematophagous arthropods after a blood meal, without implying that they act as vectors [4]. Therefore, the data presented here highlight the potential role of Oc. caspius, along with well-known vectors (i.e., Cx. pipiens s.l. and Ae. albopictus), in the transmission of Dirofilaria spp. to humans and animals in this tourist area. Aedes albopictus was found to be highly infested with $D$. immitis (MIR $=3 \%$, EIR $=3.8 \%)$, as shown previously $[6,15,51]$. Both Dirofilaria spp. were detected in Oc. caspius from Solaro, an area endemic for dirofilariasis $[6,31]$. It should be noted that this urban area is also characterized by a typical environment for mosquito development, together with the availability of definitive hosts (dogs) [31], which could explain the infestation of Oc. caspius with Dirofilaria spp. Despite the low Dirofilaria spp. infection rates of Oc. caspius (from 0.1 to $0.4 \%$ ), this is the dominant species $(86.7 \%)$ captured, therefore suggesting its possible role in their transmission $[5,52]$.

The highest infection rate with $D$. immitis and $D$. repens was detected in $C x$. pipiens s.l. mosquitoes $(\mathrm{MIR}=0.6 \%$, EIR $=0.6 \%)$ followed by Oc. caspius $(\mathrm{MIR}$ and EIR ranged from 0.1 to $0.4 \%$ ), as already documented in central European Russia, Germany, Italy, Turkey and the Republic of Belarus [53]. High positivity of $C$ x. pipiens s.l. for D. immitis and D. repens was demonstrated by both molecular and parasitological studies $[54,55]$. Finally, the absence of Dirofilaria spp. DNA from $A e$. vexans in the present study might be related to the smaller number of specimens examined $(n=6)$.

\section{Conclusions}

The present study highlights the sympatric occurrence of $D$. immitis and D. repens as well as the epidemiological pressure exerted by the length of the transmission season and the diversity of Dirofilaria spp. vectors in Corsica. We highlight public health risks, as Corsica attracts more than 750,000 visitors and their pets each year, which could pose an important risk for the transmission and spread of these zoonotic mosquito-borne filarioids. Moreover, the development of specific assays able to identify the infested/ infective mosquito species with Dirofilaria spp. are needed for an integrative surveillance approach.

\section{Abbreviations \\ MIR: Minimum infection rate; EIR: Estimated infection rate; ANCOVA: Analysis of covariance.}

\section{Acknowledgements}

We are in debt to Pauline Jourdan for providing valuable help.

\section{Authors' contributions}

$\mathrm{YL}, \mathrm{OM}, \mathrm{MV}, \mathrm{DO}$ and $\mathrm{BD}$ designed the study. $\mathrm{HBC}$ and $\mathrm{BD}$ performed field investigation. $Y L, H B C$ and NA performed laboratory analysis. $Y L$ and $S B$ carried out the analysis of data. YL and SB drafted the manuscript. BD, OM, MV and $\mathrm{DO}$ reviewed and edited the article. All authors read and approved the final manuscript

\section{Funding}

This study was supported by the French Military Health Service and the Institut-Hospitalo-Universitaire (IHU) Méditerranée Infection, the National Research Agency under the program "Investissements d'avenir", reference ANR-10-IAHU-03, the Région Provence-Alpes-Côte d'Azur and European funding FEDER PRIMI. The funding sources had no role in the design or conduct of the study; collection, management, analysis, or interpretation of the data; or preparation, review or approval of the manuscript.

Availability of data and materials

The data supporting the conclusions of this article are included within the article.

\section{Declarations}

Ethics approval and consent to participate Not applicable.

\section{Consent for publication}

Not applicable.

\section{Competing interests}

The authors declare that they have no competing interests.

\section{Author details}

${ }^{1}$ Aix Marseille Univ, IRD, AP-HM, MEPHI, Marseille, France. ${ }^{2} \mid H U$ Méditerranée Infection, Marseille, France. ${ }^{3}$ Department of Veterinary Medicine, University of Bari, Valenzano, Bari, Italy. ${ }^{4} \mathrm{OCIC}$, Office de I'Environnement de la Corse, Corte, France. ${ }^{5}$ Laboratory of Food Hygiene and Quality Insurance System (HASAQ), Higher National Veterinary School, Issad Abbes, Oued Smar, Algiers, Algeria. ${ }^{6}$ Aix Marseille Univ, IRD 190, INSERM U1207, Unité des Virus Emergents, Marseille, France. ${ }^{7}$ Ceva Santé Animale, 10, Av de la Ballastière, Libourne, France. ${ }^{8}$ Faculty of Veterinary Sciences, Bu-Ali Sina University, Hamedan, Iran. ${ }^{9}$ Animal Epidemiology Experts Group of the Military Health Service, Tours, France. 
Received: 26 April 2021 Accepted: 5 August 2021

Published online: 26 August 2021

\section{References}

1. Simón F, Siles-Lucas M, Morchón R, González-Miguel J, Mellado I, Carretón E, et al. Human and animal dirofilariasis: the emergence of a zoonotic mosaic. Clin Microbiol Rev. 2012;25:507-44.

2. Simón F, González-Miguel J, Diosdado A, Gómez PJ, Morchón R, Kartashev V. The complexity of zoonotic filariasis episystem and its consequences: a multidisciplinary view. Biomed Res Int. 2017. https:// doi.org/10.1155/2017/6436130.

3. Aonuma H, Yoshimura A, Perera N, Shinzawa N, Bando H, Oshiro S, et al. Loop-mediated isothermal amplification applied to filarial parasites detection in the mosquito vectors: Dirofilaria immitis as a study model. Parasit Vectors. 2009;2:1-7.

4. Laidoudi Y, Bedjaoui S, Medkour H, Latrofa MS, Mekroud A, Bitam I, et al. Molecular approach for the diagnosis of blood and skin canine filarioids. Microorganisms. 2020;8:1671.

5. Latrofa MS, Montarsi F, Ciocchetta S, Annoscia G, Dantas-Torres F, Ravagnan S, et al. Molecular xenomonitoring of Dirofilaria immitis and Dirofilaria repens in mosquitoes from north-eastern Italy by real-time PCR coupled with melting curve analysis. Parasit Vectors. 2012:5:1-8.

6. Tahir D, Bittar F, Barré-Cardi H, Sow D, Dahmani M, Mediannikov O, et al. Molecular survey of Dirofilaria immitis and Dirofilaria repens by new real-time TaqMan ${ }^{\circledR}$ PCR assay in dogs and mosquitoes (Diptera: Culicidae) in Corsica (France). Vet Parasitol. 2017;235:1-7.

7. Bocková E, Rudolf I, Kočišová A, Betášová L, Venclíková K, Mendel J, et al. Dirofilaria repens microfilariae in Aedes vexans mosquitoes in Slovakia. Parasitol Res. 2013;112:3465-70.

8. Zittra C, Kocziha Z, Pinnyei S, Harl J, Kieser K, Laciny A, et al. Screening blood-fed mosquitoes for the diagnosis of filarioid helminths and avian malaria. Parasit Vectors. 2015;8:1-6.

9. Cancrini G, Magi M, Gabrielli S, Arispici M, Tolari F, Dell'Omodarme M, et al. Natural vectors of dirofilariasis in rural and urban areas of the Tuscan region, central Italy. J Med Entomol. 2006:43:574-9.

10. Bocková E, Iglódyová A, Kočišová A. Potential mosquito (Diptera:Culicidae) vector of Dirofilaria repens and Dirofilaria immitis in urban areas of Eastern Slovakia. Parasitol Res. 2015:114:4487-92.

11. Kemenesi G, Kurucz K, Kepner A, Dallos B, Oldal M, Herczeg R, et al. Circulation of Dirofilaria repens, Setaria tundra, and Onchocercidae species in Hungary during the period 2011-2013. Vet Parasitol. 2015:214:108-13.

12. Sulesco T, Von Thien H, Toderas L, Toderas I, Lühken R, Tannich E. Circulation of Dirofilaria repens and Dirofilaria immitis in Moldova. Parasit Vectors. 2016;9:1-10.

13. Ionicǎ AM, Zittra C, Wimmer V, Leitner N, Votýpka J, Modrý D, et al Mosquitoes in the Danube Delta: searching for vectors of filarioid helminths and avian malaria. Parasit Vectors. 2017;10:1-6.

14. Tomazatos A, Cadar D, Török E, Maranda I, Horváth C, Keresztes L, et al. Circulation of Dirofilaria immitis and Dirofilaria repens in the Danube Delta Biosphere Reserve, Romania. Parasites Vectors. 2018;11:1-8.

15. Capelli G, Di Regalbono AF, Simonato G, Cassini R, Cazzin S, Cancrini G, et al. Risk of canine and human exposure to Dirofilaria immitis infected mosquitoes in endemic areas of Italy. Parasit Vectors. 2013;6:1-7.

16. Cancrini G, Scaramozzino P, Gabrielli S, Di Paolo M, Toma L, Romi R. Aedes albopictus and Culex pipiens implicated as natural vectors of Dirofilaria repens in central Italy. J Med Entomol. 2007:44:1064-6.

17. Czajka C, Becker N, Jöst H, Poppert S, Schmidt-Chanasit J, Krüger A, et al. Stable transmission of Dirofilaria repens nematodes, northern Germany. Emerg Infect Dis. 2014;20:329.

18. Yildirim A, Inci A, Duzlu O, Biskin Z, Ica A, Sahin I. Aedes vexans and Culex pipiens as the potential vectors of Dirofilaria immitis in Central Turkey. Vet Parasitol. 2011;178:143-7.

19. Rudolf I, Šebesta O, Mendel J, Betášová L, Bocková E, Jedličková P, et al. Zoonotic Dirofilaria repens (Nematoda: Filarioidea) in Aedes vexans mosquitoes. Czech Republic Parasitol Res. 2014;113:4663-7.
20. Kronefeld M, Kampen H, Sassnau R, Werner D. Molecular detection of Dirofilaria immitis Dirofilaria repens and Setaria tundra in mosquitoes from Germany. Parasite Vector. 2014;7:1-6.

21. Kurucz K, Kepner A, Krtinic B, Zana B, Földes F, Bányai K, et al. First molecular identification of Dirofilaria spp. (Onchocercidae) in mosquitoes from Serbia. Parasitol Res. 2016;115:3257-60.

22. Bravo-Barriga D, Parreira R, Almeida APG, Calado M, Blanco-Ciudad J, Serrano-Aguilera FJ, et al. Culex pipiens as a potential vector for transmission of Dirofilaria immitis and other unclassified Filarioidea in Southwest Spain. Vet Parasitol. 2016;223:173-80.

23. de Lahitte DJ, Davoust BDP. Filariose canine à Dirofilaria immitis. Enquête sur la fréquence et la répartition en zone méditerranéenne. Bull la Société Française Parasitol. 1984;3:105-8.

24. Joyeux CCH. Etude sur la filariose des chiens de Camargue. Bull la Société Pathol Exot. 1935;28:187-93.

25. Laidoudi Y, Ringot D, Watier-grillot S, Davoust B, Mediannikov O. A cardiac and subcutaneous canine dirofilariosis outbreak in a kennel in central France. Parasite. 2019:26:72.

26. Laidoudi Y, Otranto D, Stolowy N, Amrane S, Santhakumari Manoj RR, Polette $\mathrm{L}$, et al. Human and animal dirofilariasis in Southeast of France. Microorganisms. 2021;9:1544

27. Zahler M, Glaser B, Gothe R. Imported parasites in dogs: Dirofilaria repens and Dipetalonema reconditum]. Tierarztl Prax. 1997;25:388-92.

28. Pantchev N, Etzold M, Daugschies A, Dyachenko V. Diagnosis of imported canine filarial infections in Germany 2008-2010. Parasitol Res. 2011;109:61-76.

29. Berger SM. Infectious Diseases of France. 2019th ed. Gideon Informatics I, editor. Los angeles, California, USA: Gideon Informatics, Inc.; 2019.

30. Pampiglione S, Peraldi R, Burelli JP. Human dirofilariasis in Corsica: a new local case. Review of reported cases. Bull Soc Pathol Exot. 1999:92:305-8.

31. Laidoudi Y, Medkour H, Tahir D, Dahmana H, Marié J-L, Varloud M, et al. Field evaluation of preventive efficacy of monthly multimodal prophylactic treatment (Milbactor ${ }^{\circledR}$ and Vectra ${ }^{\circledR}$ 3D) against Dirofilaria spp. in Dogs. Parasitologia. 2021;1:130-6.

32. Cuervo PF, Rinaldi L, Cringoli G. Modeling the extrinsic incubation of Dirofilaria immitis in South America based on monthly and continuous climatic data. Vet Parasitol. 2015:209:70-5.

33. Fortin JF, Slocombe JOD. Temperature requirements for the development off Dirofilaria immitis in Aedes triseriatus and Ae. vexans. Mosq News. 1981;41:625-33.

34. Sassnau R, Daugschies A, Lendner M, Genchi C. Climate suitability for the transmission of Dirofilaria immitis and D. repens in Germany. Vet Parasitol. 2014;205:239-45.

35. Severini F, Toma L, Di Luca M, Romi R. Le zanzare italiane: generalità e identificazione degli adulti. Fragm Entomol. 2009;41:213-372.

36. Laidoudi Y, Davoust B, Varloud M, Niang EHA, Fenollar F, Mediannikov O. Development of a multiplex qPCR-based approach for the diagnosis of Dirofilaria immitis, D. repens and Acanthocheilonema reconditum. Parasit Vectors. 2020;13:1-15

37. Gu W, Lampman R, Novak RJ. Problems in estimating mosquito infection rates using minimum infection rate. J Med Entomol. 2003:40:595-6.

38. Cowling DW, Gardner IA, Johnson WO. Comparison of methods for estimation of individual-level prevalence based on pooled samples. Prev Vet Med. 1999;39:211-25

39. Genchi C, Rinaldi L, Cascone C, Mortarino M, Cringoli G. Is heartworm disease really spreading in Europe? Vet Parasitol. 2005;133:137-48.

40. Montoya-Alonso JA, Carretón E, Simón L, González-Miguel J, GarcíaGuasch L, Morchón R, et al. Prevalence of Dirofilaria immitis in dogs from Barcelona: validation of a geospatial prediction model. Vet Parasitol. 2015:215:456-9.

41. Ciuc L, Musella V, Miron LD, Maurelli MP, Cringoli G, Bosco A, et al. Geographic distribution of canine heartworm (Dirofilaria immitis) infection in stray dogs of eastern Romania. Geospatial Health. 2016. https://doi. org/10.4081/gh.2016.499.

42. Nelson CT, Mccall JW, Jones S, Moorhead A. Current canine guidelines for the prevention, diagnosis, and management of heartworm (Dirofilaria immitis) infection in dogs. Am Hear Soc. 2018; 1-35. 
43. Morchón R, Carretón E. Heartworm disease (Dirofilaria immitis) and their vectors in Europe-new distribution trends. Front Physiol. 2012;3:196.

44. Crans WJ. A classification system for mosquito life cycles: life cycle types for mosquitoes of the northeastern United States. J Vector Ecol. 2004;29:1-10

45. Mancini G, Montarsi F, Calzolari M, Capelli G, Dottori M, Ravagnan S, et al. Mosquito species involved in the circulation of West Nile and Usutu viruses in Italy. Vet Ital. 2017:53:97-110.

46. Toma L, Cipriani M, Goffredo M, Romi R, Lelli R. First report on entomological field activities for the surveillance of West Nile disease in Italy. Vet Ital. 2008:44:499-512.

47. Silaghi C, Beck R, Capelli G, Montarsi F, Mathis A. Development of Dirofilaria immitis and Dirofilaria repens in Aedes japonicus and Aedes geniculatus. Parasite Vector. 2017;10:1-13.

48. Montarsi F, Ciocchetta S, Devine G, Ravagnan S, Mutinelli F, Di Regalbono FA, et al. Development of Dirofilaria immitis within the mosquito Aedes (Finlaya) koreicus, a new invasive species for Europe. Parasites Vectors. 2015;8:1-9.

49. Montarsi F, Ciocchetta S, Ravagnan S, Simonato G, Mutinelli F, Camuffo $\mathrm{S}$, et al. Laboratory evidence on vector competence of the invasive mosquito Aedes koreicus [Hulecoeteomyia koreica] for Dirofilaria immitis. Parasit Vectors. 2014;7:1-1.

50. Tiawsirisup S, Nithiuthai S. Vector competence of Aedes aegypti (L.) and Culex quinquefasciatus (Say) for Dirofilaria immitis (Leidy). Southeast Asian J Trop Med Public Health. 2006;37(Suppl 3):110.
51. Brianti E, Panarese R, Napoli E, De Benedetto G, Gaglio G, BezerraSantos MA, et al. Dirofilaria immitis infection in the Pelagie archipelago: the southernmost hyperendemic focus in Europe. Transbound Emerg Dis. 2021. https://doi.org/10.1111/tbed.14089.

52. Rossi L, Pollono F, Meneguz PG, Cancrini G. Quattro specie di culicidi come possibili vettori di Dirofilaria immitis nella risaia piemontese. Parassitologia. 1999;41:537-42.

53. Shaikevich E, Bogacheva A, Ganushkina L. Dirofilaria and Wolbachia in mosquitoes (Diptera: Culicidae) in central European Russia and on the Black Sea coast. Parasite. 2019;26:2

54. McCall JW, Genchi C, Kramer LH, Guerrero J, Venco L. Heartworm disease in animals and humans. Adv Parasitol. 2008;66:193-285.

55. Cancrini G, Torre DA, Coluzzi M. Different probabilities of transmission of Dirofilaria immitis and D. repens by Culex pipiens. Proc 6th Eur Multicolloquium Parasitol. 1992;90.

\section{Publisher's Note}

Springer Nature remains neutral with regard to jurisdictional claims in published maps and institutional affiliations.
Ready to submit your research? Choose BMC and benefit from:

- fast, convenient online submission

- thorough peer review by experienced researchers in your field

- rapid publication on acceptance

- support for research data, including large and complex data types

- gold Open Access which fosters wider collaboration and increased citations

- maximum visibility for your research: over 100M website views per year

At BMC, research is always in progress.

Learn more biomedcentral.com/submissions 